\title{
Elizabeth Bishop's Brazil: An Attraction in Difference
}

\author{
TOM WINTERBOTTOM
}

Stanford University

\begin{abstract}
The correspondence of Elizabeth Bishop during her years in Brazil with fellow poet Robert Lowell shed light not only on her personal impressions and experience there but also on the broader atmosphere of Brazil in the 1950s and 60s. The abundant letters show an intimacy that Bishop was willing to explore in personal correspondence that was not readily forthcoming in her published poetry. The present essay analyzes that correspondence alongside the few poems Bishop wrote in or about Brazil to understand her pursuit of belonging and happiness that found an unlikely home-and a tragic end - in and around Rio de Janeiro for almost twenty years. Bishop's trajectory from love to loss and happiness to tragedy intimately interacts, this essay argues, with changes in midcentury Brazil, from the national development pursued by Vargas and Kubitschek, including the building of Brasília, to the fallout from the 1964 military coup and beyond.
\end{abstract}

Keywords: Poetry, travel, Rio de Janeiro, letters, belonging

Elizabeth Bishop's death in October 1979 marked the end of an itinerant adult life that struggled with belonging and meaning, punctuated by tragedy and depression. It was in an unexpected place, Brazil, that the poet found her home and finally, at least for a time, some degree of happiness. The difference of what she found there-an escape from the restrictions and expectations of the United States - seemed freeing, allowing her an unforeseen corporeal and creative liberation. Brazil, perhaps, is well known for this; Bishop, on the other hand, was not. She arrived in 1951 as a forty-year-old with the intention of spending two weeks in Brazil to visit friends before continuing her trip around Cape Horn. Having disembarked in Santos, she lived in Brazil for the next fifteen years, 
principally in and around Rio de Janeiro. The poet and Brazil would attune into a complex and meaningful resonance for these significant years for Bishop's life and legacy.

Bishop experienced an intense interaction with the new landscape surrounding and enveloping her, and an often-tempestuous relationship with a prominent and eccentric architect, Lota de Macedo Soares. The abundance of Brazil—of life, of nature, of happiness—interacted with both her frustrations of the "backwards" country, as she put it, and with the sense of otherness that was marked by her experiences of being in a place so foreign to her. She settled into life with Lota, writing some non-fiction and translating. However, it is her poetry and, particularly, her correspondence that shed light on her new experiences. Questions of Travel (1965) was influenced by her impressions of the southern environment and one of only four slim volumes of poetry she wrote in her life. More extensively and revealingly, however, she maintained profound and extended correspondence with fellow poet and friend Robert Lowell, collected in Words in Air (published in 2008), telling the story of her personal, intimate, and literary interaction with her adopted home. If Brazil might tell us something about Bishop, then the reverse is also certainly true.

In Question of Travel's eponymous poem, there is a sense of the power that this new world exerted over the narrator, a natural abundance influencing the physical and emotional state. The environs of Rio, near the mountain town of Petrópolis, see "too many waterfalls," where "the crowded streams hurry too rapidly down to the sea.” The clouds in Brazil are not like those she encountered elsewhere; rather, "the pressure of so many clouds on the mountaintops," as she writes, "makes them spill over the sides in soft slow motion." The emotive imagery continues, as those same clouds turn "to waterfalls under our very eyes" (8). Nature and a visceral, bodily belonging were fundamental to Bishop's existence in her adopted home, and the intensity of Brazil's natural environment was unlike anything she had previously experienced.

"Nature" in this sense is not simply a backdrop or a setting for Bishop in Rio but rather a present and interactive factor in her existence; it is a new landscape. Its abundance disconcerts and also comforts her. The first poem in Questions of Travel, "Arrival at Santos," for example, depicts the power and personality of the natural world through the intense use of adjectives that attribute physical and emotive characteristics to nature. In this poem, the scenery is "impractically 
shaped," the mountains "self-pitying," the greenery "frivolous," the pink and blue colors "feeble," and the palm trees "tall, uncertain." "Oh, tourist, is this how this country is going to answer you / and your immodest demands for a different world [...]?” (4). These poems convey a sense of (over-)abundance and of gesturing towards being sublimely overwhelmed. However, it was also in that dynamic — of how it contrasted with her more staid "home" environment in the United States-that she found attraction. That difference was for her akin to stepping into another time in another place, a liberation that the lush and complex Rio de Janeiro and its surrounding area afforded her.

This otherness of Brazil was at once both appealing - leading her to stayand a source of her frustration. The tension between her accustomed and often unsettled existence that came before (and after) her time in Brazil, and her indulgence in a new and generally happy life while in Brazil, shaped her unexpected experience. The notion of there being "too many" waterfalls going "too rapidly," or-as she wrote in 1953 to some friends - that the light and "lolloping mountains" were "too fantastic," provokes a sense of impossibility or unreality (qtd. in Goldensohn 4). ${ }^{1}$ It was a disconnected and remote reality that she lived in, a new time and rhythm of life into which she walked and uncovered a complex existential resonance, an emotive connection with Brazil that she found attractive. How to comprehend, then, this fundamental otherness that was at once defined by an often overabundant and joyful existence along with her frustrations and melancholy? For Bishop, there was an acute sense of incomprehensible and sometimes glorious difference in her adopted home.

After a few years of transience (Paris, New York, Key West, and Mexico City), Bishop arrived on the Brazilian coast in 1951 during the mid-century nationalist, modernizing impulse led by Getúlio Vargas, who committed suicide in 1954. This led to a period of upheaval, before the progressive Juscelino Kubitschek came to power, and-under the moniker of "fifty years of development in five"-promised to develop the country and to build a brandnew, modern capital, Brasília, in the middle of the country. It was a period of relative prosperity and stability, quickly followed by political unrest: 1961 saw two short-term presidents and increasing division and polarization. The right-

\footnotetext{
${ }^{1}$ As Goldensohn notes (287), these and subsequent “quoted in” citations come from unpublished prose in the Vassar College Library collections.
} 
wing populist Jânio Quadros resigned after less than seven months in office, having lost support and political majorities. Subsequent acting president Ranieri Mazzilli bridged a two-week gap before left-wing former vice president João Goulart came to power in September 1961 amid constitutional changes, causing fear among much of the conservative elite for his leftist inclinations and relations with communist countries. When the 1964 military coup ousted Goulart, Mazzilli returned as acting president for a few days before a series of military leaders ruled for the next two decades. Initial and artificial economic growth soon led to social and political fallout, causing eventual economic decline and a prolonged social and economic disaster.

Bishop, within her rarefied and wealthy circles in Brazil, lived this history and sometimes stepped into the political debate, at least on the personal level. Indeed, she and Lota were close friends with Carlos Lacerda, "a flame-throwing pamphleteer who was the government's bitterest foe” (as Benjamin Moser describes him). Lacerda initially supported the coup before later switching allegiances, much to Bishop's chagrin. Sentiments grew of a country out of control, resulting in a "nice quick revolution in the rain-all over in less than 48 hours" (Words in Air 523). Bishop become a supporter of the coup, writing in her correspondence with Lowell that "the military junta probably looks much worse from the outside than it does from here." She goes on: "The suspension of rights, dismissing lots of Congress, etc. [...] had to be done-sinister as it may sound.” For someone so restrained and painstaking in her poetry, Bishop conveys in these letters a resonance with the military coup. In that same letter to Lowell, she disparages Goulart and any communist sympathizers. "We knew things were bad," she wrote emphatically, "but I'd stopped trying to tell anyone outside the country-no one would believe me" (530). From her misguided and biased perspective as an adopted part of the conservative elite, she saw the coup as a necessary move. ${ }^{2}$ However, the progressive dismantling of society, economic crisis, and tense atmosphere would define-and eventually put an end to-her remaining years there as she suffered personal, social, and existential crises.

\footnotetext{
${ }^{2}$ Her support for the coup has caused significant controversy in contemporary Brazil: she was chosen as the autora homenageada of the 2020 and eighteenth edition of the prestigious International Literary Festival of Paraty for her "olhar estrangeiro e conflituoso," the first foreign author (and fourth woman) to receive the accolade. But artistic creation and personal perspectives were not easily separated: her support for the coup has caused outrage in Brazil's current political climate and jeopardized her place in the Brazilian literary and cultural canon.
} 
Brazil's changing international status, from the "country of the future" in the mid-century moment and what some called the "most modern country in the world" for some of its architectural projects, to instability and fallout in the 1960s and 1970s, accompanies and contextualizes Bishop's experience. ${ }^{3}$ Where she had once been able to "loll" in her new world, despite-or, more likely, precisely because of-it being, in her words, a "glorious mess" and a place of "superb underdevelopment," she eventually was obliged to leave: her relationship was over, her partner dead, with Brazil no longer feeling like home.

Having arrived to visit Brazil and see friends for two weeks, Bishop fell ill following an allergic reaction. Lota, one of her acquaintances there, helped her recuperate, and their relationship soon became amorous. Bishop permanently moved in with Lota near Petrópolis and they kept a pied-à-terre in Copacabana. At the time, Lota was having an "ultra-modern” house-as Bishop wrote—called Samambaia constructed deep within the jungle. Without having planned it, piece by piece her prolonged stay came about as she found herself surprisingly at home in this new world of contrasts. ${ }^{4}$

Bishop uncovered in herself a child-like sensation of indulgence and freedom coupled with the feeling of otherworldliness. When she visited a friend recuperating after a bout with yellow fever, the friend looked out of the window and commented that the scenery could have been something conjured or imagined by an eight-year-old boy. Bishop notes,

\footnotetext{
3 The Austrian-Jewish author Stefan Zweig lived in Brazil and published Brazil, Land of the Future in 1941, presenting a favorable image of his new home (arriving in 1940, he would commit suicide in Petrópolis in 1942) and of the Vargas regime, creating a dreamy and peaceful landscape in stark contrast to the Europe he had left behind. During global upheaval in the 1940s, Vargas's Brazil crafted an image of progress and modernity to become, as Richard Williams writes, "the country that had bought into the idea of modernity most comprehensively," wishing to "remake itself in that image" (3).

${ }^{4}$ See Bethany Hicok for further details on Bishop's activities in Brazil. The 2013 film Flores raras (Reaching for the moon) tells Bishop and Lota's story. One fictional monologue from Bishop's character rings true with sentiments in her actual correspondence: "How can one live in a place," she asks, "where stamps come unglued, soap melts almost before you can use it, and rivers run too fast to the sea? I would like to understand this unbearable joy Brazilians have, this constant urge to celebrate. And there's your melancholy, its drama, its flamboyance; [...] it's out of proportion, excessive.”
} 
And it did look like a child's drawing! Four or five unreal peaks; two cable cars dangling on wires; planes landing and taking off; lights coming on all round the bay and a huge signboard giving the hours and the news.... Goats lounging on a little footbridge, looking down enthralled by the "roosh"-all the elements were there to delight the heart of a child — and yet altogether a delicate and slightly mad beauty (qtd. in Goldensohn, 3-4).

The "unreal" and the clear mix of the old and the new-the airport and the goats, the speed of the automobiles - sees delight not only for a child but for Bishop herself, resonating with the "mad beauty," almost as though she felt like she had traveled in time. Santos Dumont airport, a futuristic Modernist building completed in 1947, sat juxtaposed with the goats on the bridge and nature all around. The new cars raced along one of Vargas's new roads just like the futurist Filippo Marinetti had imagined years earlier on a visit to Brazil. Living in this environment was, for her, an otherworldly indulgence in a life that she had not experienced before: it was both beautiful but also impossible to comprehend. Bishop reveled in that dynamic, finally finding a happy home in her tumultuous and traumatic life, one that had been robbed in its early years of any significant childhood joy.

The essence of Bishop's attraction as well as her recognition and reflection of the difference of her adopted environment and its fundamental pull on her being comes across in the poem "Questions of Travel." "Think of the long trip home," she writes, "Should we have stayed at home and thought of here?” But, she asks, what is this "breath of life" in our bodies that brings out a certain "childishness" that makes us "rush to see the sun the other way around?" (4). The attraction that she felt, coupled with this sense of both indulgence and reflection, orients her time in Brazil, and she more than once refers to it as a childish impulse. Her hemispheric transition played on her and was a constant point of reference throughout the time that she was not "at home" in the US. After all, we tend to know where we are from whether we like it or not, and in Bishop's case, "home” was always complicated. Bishop's relationship with a place and an individual, and her way of reflecting on her status there through correspondence and poetry to an outside audience, affords an explicit sensation of both belonging and not belonging. Where was her home, though, if not in the unreal, mad, and 
Winterbottom

disconnected beauty that she found in Brazil, the one place where she confessed to being happy? Bishop lived this existential conflict in terms of happiness and homeland, becoming in a novel way a part of a deeper intellectual question: where, and what, is one's homeland? Brazil became Bishop's home, but there was always a degree of in-betweenness to her life there. ${ }^{5}$

A sense of nostalgia defined her experience: for how things were different in Brazil (for better or for worse) from how they were in the United States, or for how they could have been better in Brazil. Yet, somehow, she found herself happy in that strange, adopted environment. On an intimate and personal level, she felt as though she had traveled through time by moving to this tropical environment of inexplicable and unforeseen contrasts. She indulged in Brazil's apparent outdatedness and abandon, which allowed her to express her latent childlike instinct. It was, at once, the country "of the future,” as Zweig famously wrote of it, where she lived in an avant-garde house with a modernist, and yet it was also a "poor country with its feudal Portuguese adventurers trying to pretend they're twentieth-century democrats” (Words in Air 536).

The extreme happiness Bishop found in Brazil contrasts with her having been "miserably lonely" in New York, leading her to "feel as if I must have died and gone to heaven without deserving to" when she got to Brazil (qtd. in Goldensohn 9). The feeling of traveling forward in time, to an ostensibly modernizing urban Brazil of state-sponsored, futuristic Modernism, was confused by what she saw on the ground (the goats, the poverty, and the favelas, for example), which struck her as backward and stuck in the past. It is in this contrast and temporal complexity that Bishop experienced Brazil.

The tragic aspect of Bishop's life in Rio is embodied by her relationship with Lota. Bishop, a somewhat introverted and meticulous North American, encountered Carlota de Macedo Soares-a charismatic, bold, and funny Brazilian socialite architect—during her first days in Rio de Janeiro. Lota came from a prominent family, influential and well connected, counting Lacerda-the

\footnotetext{
${ }^{5}$ Historically, and particularly in the nineteenth and early twentieth centuries, Joaquim Nabuco and other Brazilian intellectuals also showed this duality of belonging: a sense of intimacy with Europe as the center of history, science, progress, and reason, while also recognizing Brazil as a place of the new, of abundant nature, and as their homeland. The "dilema do mazombo"-a term written about Nabuco's work Minha formação and named for Brazilians of European ancestry-exposes those questions of homeland and belonging. Mário de Andrade, in the vein of Brazilian modernists who had less of an interest in looking to Europe, sarcastically called it "a doença de Nabuco."
} 
future governor of Rio de Janeiro-among her close friends. Bishop, meanwhile, was effectively an orphan, her father having died when she was less than a year old and her mother institutionalized four years later. That led Bishop to be moved from Massachusetts to live with her grandparents in Nova Scotia before subsequent frequent moves around the American Northeast, a childhood of trauma, abuse, and loss that informed her whole life. Along with the impact of the new environment on her, it was her relationship and nascent intimacy with Lota that led Bishop to stay-happily-in Brazil. There she was able to express herself in a different way and according to a different rhythm of life, a feeling of decadent escapism and the opportunity to lead an expressive, indulgent, and privileged life that felt far removed from her stifling northern reality.

Bishop moved in with Lota soon after her arrival (Lota was at the time living with another woman, Mary Morse), and they soon came to live together as lovers. Lota, with her status and connections, afforded Bishop a peaceful, rural space to write, as well as a readymade network of friends and acquaintances-finally a “family," as Bishop called it. She wrote, traveled on occasional trips abroad (and frequently to Ouro Preto, where she bought a house in 1965), and removed herself from many of the social and personal restraints that she had encountered elsewhere, as well as working at battling her chronic illnesses and alcoholism. In 1952, months after arriving, she looked out from her room "at seven in the morning" to see her "hostess in a bathrobe directing the blowing up of a huge boulder," presumably in the building of their new house set within the jungle. She found in Lota a kinship that helped her work more and drink less, a result of her hostess's "good sense and kindness" (qtd. in Goldensohn 10). Different though they were, in their contrasts they found an emotional connection and resonance.

As time passed, however, the situation deteriorated. For both, the heavy drinking resumed. Adultery and bitter fights became part of their relationship. Lota saw many of her friendships sour following the military coup in 1964, and for Bishop the contrasting and increasingly tense environment around her brought pressure onto their relationship. It led to breakdown: from what had been an indulgent, harmonious relationship of expression and general happiness found in the contrasts, one sees a transition into decline and deterioration that culminated in Bishop having to abandon Brazil, rejected and alone. The charismatic, larger-than-life Lota, meanwhile, had fallen into a drastic 
Winterbottom

depression, and she ultimately committed suicide in 1967 while in the United States to reconcile with Bishop following the latter's return to the bottle and infidelity.

In 1968, Bishop published "Going to the Bakery," and her earlier rural sensibility and the positive emotive impact from the previously happy environment — characterized by the abundance of nature in her earlier poemsis replaced by a gritty, urban, and depressed picture of the Brazil under military rule with which she had fallen out of step. The lights in the bakery are now dim due to rationed electricity. Even the cakes "look about to faint," and the tarts "are red and sore" (Poems 173). Both are made from flour that is now "adulterated with cornmeal" (173). The different rhythm of life-once so appealing-is now frustrating. There is suddenly an aesthetic of hunger and scarcity, not abundance, where an atmosphere of (urban) decline has replaced spectacular and resplendent nature, and in which her foreignness suddenly becomes acute: she feels compelled, later in the poem, to give a drunken, black beggar "seven cents in my terrific money” (174). If she had never fully belonged in Rio, feeling out of place and in a different time, the feeling of difference had now become too much to bear.

"Write soon and tell us about Brazil. Why Brazil? That's what everyone asks us" (Words in Air 133). This is the first (and ever-present) question that Robert Lowell posed to Elizabeth Bishop on learning that she was going to "visit Rio for a while" (129), encapsulating his perplexity. "I wasn't even particularly interested in Brazil to start with,” she replies, having only stopped there for a brief visit before being drawn in: "Lota de M-S-my hostess, has an apartment there [in Rio] on that famous carte postale beach but lives mostly in the country, though that gentle expression scarcely seems to fit, in Petrópolis, a mountain resort about 40 miles off - magnificent and wild. She is building an ultra-modern house up on the side of a black granite mountain” (134).

Nature and its impact permeate Bishop's writing, as evidenced in her poetry and in this letter, with a sense of being somewhere "wild" that is at the same time inevitably "magnificent." The contrast is fascinating: within the jungle, an indescribable space where "that gentle expression ['the country'] scarcely seems to fit," she lives in that avant-garde Modernist home in a country that was, in 1952, internationally famous for its architectural Modernism. As such, her first experiential contrast arises between the lush natural world and this ultra-modern 
architecture, a sentiment creatively reinforced as an existential consideration for Bishop in her poem "Song for the Rainy Season," in which she observes her house that is "hidden in the high fog [...] beneath the magnetic rock," where nature is abundant and overpowering: "bromelias, lichens, / owls, and the lint / of the waterfalls cling, / familiar, unbidden” (Questions of Travel 16).

The abundance of nature strikes Bishop, as does the contrast between nature and built environments. Perhaps more prosaically, food is also a locus of remarkable contrast for her, insofar as it is served "un-shelled, unblanched, unskinned, or un-dead" (Words in Air 134). There she learned "to cook goat [...] with wine sauce”, giving her an exotic sensation of difference (134). The vitality, intrigue, and otherness of Bishop's surroundings evoke lengthy descriptive reflections. "I find it hard to stop when I get to describing," she wrote, struck by the novelty of her new world and its sensory impact (134). "It is starting to get dark and I am up at my estudio [sic] without a lamp, and I don't hear any signs of our generator's being started, so I must clamber down the mountain and start it myself [...]. In six months or so there will be electricity all the way up here" (155-56). Bishop clearly enjoyed how the incipient ultra-modern style ("of the future") contrasted with the present experience of rural withdrawal and of perceived backwardness. The state of flux - the sensation of unpresentness and displacement-that she found in Brazil was an atmosphere that deeply, emotively, and sometimes seemingly illogically appealed to her.

A trend that defines most of Bishop's time in Brazil is the difficulty to come to terms with the place while also being unable to leave. And there is good reason why she cannot leave: "Here I am extremely happy, for the first time in my life [...]. I find the people frank, startlingly so [...] extremely affectionate, an atmosphere I just lap up-no I guess I mean loll in” (143). The joie de vivre and the sense of having discovered herself in this new environment are apparent, at least on the intimate and personal level of her emotional state: existentially, for Bishop "home" not only signifies birthplace but also the place that grants individual renewal. She enjoyed her relationship with Lota, and their high-class life was satisfying and expressive, at least in the earlier years. When she writes about Brazil more broadly, however, the tone fluctuates and often sours: "Brazil really is a horror; but sometime I must tell you more. You would be really fascinated by the family histories. Rio society is beyond belief. Proust in the tropics with a samba instead of Vinteuil's little phrase-no that's cheap,- - but 
Winterbottom

sort of" (143). That impression of society, particularly from her privileged and wealthy position, builds on an impression that she wrote weeks earlier about "how it simplifies things to have almost no middle class" (135). The contrasting aspect of Brazilian society had a rapid and profound impact on her, the fluctuation between happiness and frustration seeming to be an important part of their attuned existence.

Through the abundance of nature, the mix of futurity and backwardness, and the intensity of social inequality, one finds Bishop living a surreal and otherworldly existence. She is an American poet who has fallen in love with Rio and its surrounding areas. She is happy there, away from home, and she witnesses and talks about its contradictions and idiosyncrasies frequently. She often compares Brazil to life elsewhere in Europe or North America, where existence has distinct parameters from what she experienced in and around Rio. It is precisely these idiosyncrasies that, for Bishop and many other foreign visitors, generate part of the attraction and joy that are - on the individual level at leastoften stereotypically associated with Brazil. She writes of Rio's Carnival, for example, as a "big glorious mess," a sentiment that echoes the hectic and chaotic aspect of the city's beauty that contributes to its beguiling charm and that is also part of its perceived inefficiency and frustrations. Both contribute to the sublime atmosphere of the city and its vibrant life and aesthetic appeal, where "at night the lovers on the mosaic sidewalk cast enormous long shadows over the soiled sand” (274). She writes to Lowell: "I think you'd like it” (274). But her great friend never did visit.

It is not only for the displaced Bishop that being happy dialogued with a sense of absence. Despite the abundance, plenitude, and indulgence, there is the sensation that something was always missing for Lota, too, an elite Brazilian. She talks (through the narrator in the letters) of her frustration with the country, a desire-whether pursued or not—for something different, the reverse of the experience that Bishop had had initially: "[Lota is] very fed up with Brazil, as all the Brazilians I’ve met are. They yearn for 1. Paris, 2. New York. (NY is a recent taste, just 10 years old-it was considered rather vulgar to go there before)" (134). A feeling of disquiet and a projection elsewhere defines the present, but it is - in their intimate context at least - the sensation of vivid contrast that lent Brazil a significant part of its attraction. It was an indulgence that convinced them 
to stay, happy for the most part, while also feeling nostalgia for something perceived not to be there- a defining and perpetual feeling of Brazilian saudade.

Brazil, despite being "full of Brazilian drivers, who never bother to learn at all," is "wonderful for me now, and it really looks as though I'd stay. By next spring I think I'll be able to go away - probably to Europe, for about six months. The next trip will be to New York, for a winter, I imagine. But I don't feel 'out of touch' or 'expatriated' or anything like that, or suffer from a lack of intellectual life, etc.” (142). As a writer, Bishop needed to feel "in touch" (to be able to send articles and work to her publishers) and she managed, despite the inefficient postal service and bureaucratic customs (something she writes about at another moment). It is not that she is out of touch, perhaps, but rather that she is connected to the world in a new, different manner and existing according to a distinct temporality. In Brazil, it is implied, life transpires with alternative parameters and adheres to a different rhythm when compared to the United States or Europe: being corporeally and aesthetically "in touch" yet also "backwards" in terms of getting things done. She could be, perhaps, strikingly intimate on the personal level and liberatingly expressive on the social level, allowed to show both abundant joy and flamboyant melancholy. These are not necessarily opposites: they are vital, interactive, and identifying elements in a dynamic, evolving, attractively frustrating whole that is idiosyncratic in its sublime beauty. For Bishop, the attraction lay in that existential difference.

When, for example, the Eucharist Congress came to Rio, she explicitly notes that there are "600,000 pilgrims expected, a dreadful water-shortage, not much food, and either typhus or typhoid, I don't know which, already going. It promises to be too, too medieval” (159). Around that same time, relatively early in her time in Rio, “food prices have gone up 300\% since I've been here-most things accordingly" (148). Yet still she felt liberated by her (wealthy, privileged) experience of this renewed existence, an indulgence of the difference she found in Brazil. Bishop herself sums it up wonderfully: when referring to an art installation that was created near their Petrópolis house, she writes: "the best of the 'modern' architects did it. But everything here is that confusing mixture of good and bad taste, the absurd and the sad, and the natural and spontaneous \& charming” (166). Summing up her unexpected and hard-to-rationalize attraction, she wrote to Lowell that "I am extremely happy here, although I can't quite get used to being 'happy”' (164). She had managed to separate herself from the 
Winterbottom

conflicted societal situation, undergoing instead a singularization that permitted self-renewal in the most unexpected of contexts. This, too, would come to a gradual end as military rule wore on.

Towards the end of Bishop's time in Brazil, as the socio-political situation declined further, the city became less hospitable. "It is fearfully HOT here \& we have water-rationing and light-rationing - sit with candles and a hot oil lamp from 8 to 10 each night. City life is getting worse \& worse-we really can't take it” (616). She had already channeled an ingenious way of conceptualizing the country: "[Bernard] Rudofsky (he used to live here, you know) is funny-[he] speaks of a 'superbly underdeveloped country'-(I am using this in a poem)” (566). Her very happiness stemmed from that sensation of non-belonging and of being an outsider in which she found her adopted home both "superb" and "underdeveloped." Her impression of supposed "underdevelopment," while at times frustrating for her, was not negative or something to be necessarily changed - it was just different, an expression of her idiosyncratic experience. It was in those contrasts and differences she found existential resonance, and forever more she maintained a complex (and unexpected) intimacy with Brazil.

The notion of "superb underdevelopment" wonderfully captures the situation as Bishop experienced it: a deeply appealing, attractive, and liberating environment that was-according to her North American parameters-not as modern or developed as other places, which were in her experience paradoxically places of sadness, boredom, and depression. Her unexpected joie de vivre there can be read as an aesthetic consideration seen in the (physical) mix of crumbling buildings and ruins existing alongside the ultra-modern and the new: it incorporates the incompleteness and outdatedness of Brazil (and particularly Rio) that is both deeply defined by the future and by the past; it is a perpetual Brazilian status of complete imperfection or, perhaps, incomplete perfection.

The quixotic and ongoing quest no longer to be considered underdeveloped was firmly underway in mid-century Brazil, a mentality that persists until today. In the 1950s, the state-sponsored Modernist architectural and political impulse was supposed to find its catharsis in 1960: while Bishop lived in Rio, Brasília was being built. At the same time, she found Rio "crazier than ever. There is no water in parts of the city, and the gas has been going off; one elevator works in each building and there are endless queues, blocks long, to get on every tiny brilliantly enameled bus or every old open trolley car” (255). As she sees the 
decay before her eyes, the talk of the far-away capital piques her interest: "Brazil is constructing a brand-new capital away off in the interior where there wasn't even a road until a year ago. They say it is exactly like a frontier town in the movies at present, a line of temporary wooden buildings, bars and motels, and a street of mud. I'd like to go see it” (255). She wrote this in April 1958, 18 months after construction began, although she was not in favor of the building of Brasília. She argued with John Dos Passos, who had come to write a piece about it for the US press ("our opinions on Brasília were violently opposed," she wrote), before accompanying Aldous Huxley and his second wife on a trip there.

It was not, however, the emerging city that got her attention. "They were sent on a trip to Brasília and then beyond, with the Air Force, to see some Indians, and I went along, the best trip I've made here so far," she confesses. "I don't know how you feel about Indians. I had expected to be depressed by them, the most primitive people alive except for the pygmies, but actually we had a wonderful cheerful time. It's only depressing to think about their future” (264). She seems to see for the first time-rather than focusing on the new, futuristic capital being built - the presumed antithesis to forward-looking modernity, the native populations who have been and continue to be systematically repressed and persecuted in the name of development or modernization. It is there, paradoxically, that Bishop seems to encounter a certain new intimacy (despite her objectionable language) concerning the presence and role of indigenous populations in the Brazilian imaginary. Surprised, if a little depressed, by her reaction to the indigenous peoples_-including those with whom she spent time alongside Huxley on the Xingu river-she unwittingly makes an important observation. The complex coming-together of these two distinct timeframesthe "new" capital "of the future" and the "old" culture of the peoples "of the past" - is a backbone of the nation's republican identity, perpetually and dynamically evolving in a present that always seems "almost" about to change, finally "leaving behind" this unsavory, "pre-modern" aspect of its history. It is a dominant trend that identifies the Brazilian socio-political atmosphere then as much as it does now (for example, Jair Bolsonaro's recent promises of development while pointing to indigenous communities as a primary obstacle of economic growth), or indeed in many moments since the birth of modern Brazil in 1889. 
Winterbottom

“Things in Brazil still sound a bit confused," Lowell wrote to Bishop as the social and political situation became ever more complex following 1964 (448). He could not have said it better. As much because of the social and political context, he was also struck by the mood swings in Bishop's letters-from passion and attachment to increasing frustration and rejection-that fueled her personal confusion. Accentuated by the decay around her, Bishop's alienation was increasingly acute as her status with Lota and their friends became more tense. Despite the subsequent breakdown of her situation and the tragic death of Lota, circumstances which meant that Bishop never returned to live in Brazil, the poet maintained for the last years of her life a fond attraction to the environment that she had made her home.

"I am utterly sick of public Brazil, political Brazil,” Bishop writes (458), and then, "I'm horribly depressed about what's going to be happening here and my one thought is to get away from it for awhile" (526). The positive reflections become less and less apparent in her correspondence as the 1960s progress. Concurrently, the more time she spent there, the more she reflected existentially and nostalgically on her situation. "This isn't my world —or is it?" she asks herself, before rapidly and resoundingly coming up with her answer less than a month later (531). From a physical and mental distance, and just prior to Lota's suicide, she writes: "WHAT a relief to get away from this poor country with its feudal Portuguese adventurers trying to pretend they're $20^{\text {th }}$ century democrats, etc.-I send you lots of love and lots of fond but jumbled emotions, like nostalgia, etc.” (536). Her status and situation were more confused than ever, laced with an extremity of dislocation and deep melancholy.

Bishop's explicit frustration also came to the fore in this period: she becomes increasingly defined not by affection but rather by a feeling of superiority. Rio becomes more backward, more (negatively) outdated, a more difficult place to exist, and—she implies—populated by less cultured people. "If you never see a real Picasso, you pretend Portinari's good —or if you have never in your life heard any good music - you pretend 'Bossa Nova' is good, or Villa Lobos the greatest, etc.” (472). In this manner, her sense of difference becomes acute to the point of being obstinate and hierarchical. Where previously this difference had been the source of her attraction it now repels her from her adopted home; she is orphaned and uprooted once more. Her disdain and distance are cemented: "how awful to be a Brazilian, is all I can think" (538). This "home” where she was 
"happy" and had a "family" descended into a state of existential disrepair. Tragedy, as William Boyd writes for The Guardian, is "too bland" a word for the conclusion to Bishop's Brazilian adventure (and life more broadly, perhaps): "Blame, guilt, incomprehension, complete emotional trauma, personal collapse all swept in [...]. Everything seemed to be going wrong [...]. Bishop's eventual departure from the place that she had loved, and that had made her as a poet, was fraught, shaming and embittering."

As the sensation of decline and decay around her increased, and Bishop's relationship with Lota foundered due to smoldering affairs and alcoholism in an increasingly destructive atmosphere, the American poet sought out a new Samambaia. In Ouro Preto, one of her favored destinations, she bought a semiruined house in 1965 and set about restoring it. Lota did not like Ouro Preto, nor the house, and the schism between them was reiterated by Bishop's desire to get away from Rio. Lota traveled to New York to visit Bishop in 1967 to try to repair things between them, but the trip ended in tragedy when she overdosed and died a few days later. Bishop briefly went back to Brazil to take care of her business, and she never returned to live either in Petrópolis or Ouro Preto.

The bitterness surrounding Brazil did not subside after Bishop’s departure. In a letter to Lowell, she wrote, "well, backward countries produce backward and irrational people, as I should have learned by now [...] Oh god-the awful waste of a country like that—ours, too, but surely not as bad...” (Words in Air 637). Such a stark, damning vision (and one marked by an intuition of bitter superiority) affirms the sense of otherness in a particularly negative guise: where once she had felt like she belonged, enjoyed herself, and been able to indulge in a desired, decadent lifestyle, the change in her personal life and politics around her led to a rejection by and ejection from the country. It was more than a simple decline and falling out of love, it was the complete destruction of an emotional environment: "But all the business in Brazil hangs over me, a very black cloud indeed. It is strange to feel so misunderstood, even hated, there.” Her friends, or "people I had thought were my friends for almost 16 years," abandoned her, and Brazil seemed to leave her just as she left Brazil (640).

Lowell would write to her, "Darling, forget your troubles in Brazil," and with that her personal and intimate connection ends (640). Bishop still owned the house in Ouro Preto, and she returned there in 1970-71 and on her last trip to Brazil in 1974, when she was feeling increasingly ill and isolated. The good times 
Winterbottom

had passed, and all that was left was nostalgia, a remembrance of when and where she had once felt most at home before ending up abandoned and alone. What she had found in that time, however, was the precise sensation of escapism, of feeling out of place and out of her time in a landscape where she could finally live her life and be-for a period at least-happy. Perhaps it comes down to creativity and meaning: she arrived in Brazil with little poetry published and feeling stifled in North America; in Brazil, she could be happy for her existential regeneration that harbored her most creative and productive years of poetry, translation, and correspondence and an intellectual belonging on her terms.

The first half of Questions of Travel, dedicated to Lota, is entitled "Brazil" (the second half is "Elsewhere”). The collection's eponymous poem talks of the "too many waterfalls" and of the overt and impressing presence of nature. However, there is also a subtle treatment of Brazil in terms of its identity and characteristic qualities, a sense of the otherness and difference of her new home, a place where life - for better or for worse but ultimately attractive to Bishopis not always in organized harmony. When in the poem they stop for gas, she hears the "sad, two-noted, wooden tune / of disparate wooden clogs" on the stained and oily floor of the gas station and adds a parenthetical aside that highlights how different she found Brazil: "In another country the clogs would all be tested. / Each pair would have identical pitch” (9).

"On the fair green hills of Rio," she writes in "The Burglar of Babylon," "there grows a fearful stain: the poor who come to Rio / And can't go home again” (27). The poem tells the story of Micuçú, a burglar and killer and "enemy of society," who has escaped from prison and is trying to avoid being recaptured. The poem delicately portrays the interaction and coexistence of rich and poor in the city, the socioeconomic and racial contrast, and the reaction of the police in searching for him. They are hunting him down, circling over the favelas in helicopters while well-to-do residents watch the drama unfold from the safety of their apartments. One of the police officers accidentally shoots and kills the officer in command, and the hunt goes on until Micuçú is found and killed with just a revolver in his hand, the clothes on his back, and a couple of coins in his pocket. It is a story that still resonates in Brazil today, and particularly in Rio, one of the most violent cities in the world. This is what development looks like, Bishop implies: a (violent) quest for an impossible future. 
From his hideout in the Morro da Babilônia favela, Micuçú sees the beachside apartments and people swimming in the ocean. In return, the "rich people in apartments / Watched through binoculars" (30). From where he is, he uses the natural world — the hills, the grass, the birds - to find solace and to hide himself from the police helicopter circling above. The contrast between natural and urban, rich and poor, white and black are acutely present within the condensed whole of Rio. It was in this context that Bishop experienced intimate, aesthetic attraction and frustration, contributing to her sense of seemingly surreal intimacy with this place. It was somehow perfect in its improbability. "There are wonderful birds now," she wrote to Lowell in a letter. "One a blood-red, very quick, who perches on the very tops of the trees and screams to his two mateswife and mistress I presume, again in the Brazilian manner" (Words in Air 275).

Why Brazil? Lowell's question lingers. For all the complexities of Bishop's experiences there and her poetic production, an answer is even less pragmatically obvious. Why there and not elsewhere? To her foreign eyes - when she first arrived, with a couple of contacts and for a couple of weeks - she found an enigmatic happiness, at least for a time. A belonging and-finally - a root in a world that happened to be, perhaps had to be, far away from where, and who, she was born.

In Bishop's most famous poem, “One Art” (1976), published years after she left Brazil, she reconciles her mixed emotions of loss, love, and happiness in a strikingly nostalgic reflection that nonetheless bears her classic poetic subtlety. "The art of losing isn't hard to master," she writes, and it is something that we must practice doing, "losing farther, losing faster." It will not, after all, "bring disaster." And then she gets personal: "I lost two cities, lovely ones," before alluding to her relationship with Lota: "—Even losing you (the joking voice, a gesture / I love) I shan't have lied," because even though it may look "like disaster," losing someone or something or some place is actually just another art that is "not too hard to master," despite how it makes one feel (Poems 198-99). This villanelle coincides with Bishop's relationship with Alice Methfessel, a younger partner with whom Bishop traveled and lived from 1971 until the poet's death in 1979. Yet the sentiment of loss — of an older woman looking back-is as much about Brazil as it is about Bishop's final years, and it embodies her nostalgic and descriptive yet subtly reflective observation. For a time, in Brazil, she had been happy, and if nothing else, she had mastered the art of loss, of 
absence and saudades, a sublime experience she never anticipated and would never repeat.

The connection that Bishop developed with Brazil, impacted by the irrepressible and seemingly impossible natural surroundings, was clearly an escape, the release of a pressure valve linked to her stifled prior life. It was also more, however, than simply an escape. Her life there gave her an intimate, corporeal attraction to place that revealed itself to be unexpectedly in stark contrast to the lack of belonging she had felt before in North America and its literary circles. Brazil gave her both distance and intimacy, separation and closeness; there was a mutual respect, it seemed, an existential resonance that was-for a time, at least-in tune. The end, however, was a dramatic and tragic fallout from which she never again found her tenuous footing in life.

\section{Works Cited}

Bishop, Elizabeth. Poems. Farrar, Straus and Giroux, 2011.

-. Questions of Travel. Farrar, Straus and Giroux, 1965.

-, et al. Words in Air: The Complete Correspondence between Elizabeth Bishop and Robert Lowell. Farrar, Straus and Giroux, 2010.

Boyd, William. “'Must We Dream Our Dreams?’” The Guardian, 11 Sept. 2010, theguardian.com/books/2010/sep/11/william-boyd-elizabeth-bishopbrazil.

Goldensohn, Lorrie. Elizabeth Bishop: The Biography of a Poetry. Columbia UP, 1993.

Hicok, Bethany. Elizabeth Bishop’s Brazil. U of Virginia P, 2016.

Moser, Benjamin. “Elizabeth Bishop’s Misunderstood 'Brazil.”' The New Yorker, 5 Dec. 2012, newyorker.com/books/page-turner/elizabethbishops-misunderstood-brazil.

Williams, Richard. Brazil: Modern Architectures in History. Reaktion, 2009.

Zweig, Stefan. Brazil, Land of the Future. Translated by Andrew St. James, Viking, 1942. 